\title{
Erratum: Iron biofortification and homeostasis in transgenic cassava roots expressing an algal iron assimilatory protein, FEA1
}

\section{Richard Sayre*}

New Mexico Consortium at Los Alamos National Labs, Biolabs, Los Alamos, NM, USA

${ }^{*}$ Correspondence: rsayre@newmexicoconsortium.org

Edited by:

Burkhard Schulz, Purdue University, USA

Keywords: cassava, iron, transgenes, FEA1, biofortification

\section{An erratum on}

Iron biofortification and homeostasis in transgenic cassava roots expressing the algal iron assimilatory gene, FEA1

by Ihemere, U. E., Narayanan, N. N., and Sayre, R. T. (2012). Front. Plant Sci. 3:171. doi: $10.3389 / f p l s .2012 .00171$

In this article, there is a typo error and needs to be changed and corrected.
Pg. 12; Line 22 - MeFER2 and MeFER6 should be replaced by "MeFER1 and MeFER3."

Received: 18 October 2013; accepted: 15 November 2013; published online: 03 December 2013.

Citation: Sayre $R$ (2013) Erratum: Iron biofortification and homeostasis in transgenic cassava roots expressing an algal iron assimilatory protein, FEA1. Front. Plant Sci. 4:492. doi: 10.3389/fpls. 2013.00492
This article was submitted to Plant Physiology, a section of the journal Frontiers in Plant Science.

Copyright (c) 2013 Sayre. This is an openaccess article distributed under the terms of the Creative Commons Attribution License (CCBY). The use, distribution or reproduction in other forums is permitted, provided the original author(s) or licensor are credited and that the original publication in this journal is cited, in accordance with accepted academic practice. No use, distribution or reproduction is permitted which does not comply with these terms. 